$\stackrel{\odot}{\text { II }}$

\title{
BRAK KANONU I RESENTYMENT WSPÓKCZESNEGO HUMANISTY
}

ABSTRACT. Agnieszka Doda-Wyszyńska, Brak kanonu i resentyment współczesnego humanisty [Absence
of the canon and ressentiment of a contemporary humanist] edited by M. Obrębska, G. Dziamski,
"Człowiek i Społeczeństwo" vol. XLIX: Humanistyka jutra [Humanities of Tomorrow], Poznań 2020,
pp. 13-33, Adam Mickiewicz University. ISSN 0239-3271.

A canon is a word of religious origin. It constituted a basic aim of education at the university level. However, that time came to an end when the idea of universality was replaced with the idea of perfection (implicitly a clerk-like perfection). Ressentiment (a repressed feeling, described by Nietzsche and later by Scheler) acts against a higher ability to enjoy cultural pleasure; it creates a contemporary human as a man of labour and utility who cannot make use of the so-called cultural assets (from the canon). Depending on which field the idea of a canon refers to, we will understand it as such. It is most associated with art where it functions as a set of models, rules and methods of creation current in a given period of culture. There are three semantic fields of the background needed to examine the notion of a canon: culture, time and space (I dedicated two chapters of the paper to each). Today, a humanist has completely new roles, since not only did culture change but also time and space the basic "forms of sensuality", which Kant defined as our main point of orientation and a ground for thinking about the world. Coping with the canon was mainly intended to teach good choices, not only the choices regarding texts. It may be the most important mission of humanists: to show the canon and teach how to choose one of our own. Now we are observing a kind of fear of the canon (Bloom). We are irritated with what we cannot understand. The biggest load of ressentiment lies within society, in which social equality, both political and formal, goes hand in hand with very large discrepancies in terms of actual power, wealth and education. Today, humanist reflection on culture even left the political level, related to knowledge, and entered a lower, more fundamental level connected with satisfying basic needs. The only role of a contemporary "humanist" is to free themself of illusions, i.e. also of the excess of texts. Our globalised space is ruled by quick rankings and summaries of texts. We lost the need to which art responded - to determine the eternal perspective of life.

Agnieszka Doda-Wyszyńska, Uniwersytet im. Adama Mickiewicza w Poznaniu, Wydział Antropologii i Kulturoznawstwa, Szkoła Nauk Humanistycznych, Zakład Semiotyki Kultury, ul. Szamarzewskiego 89, 60-568 Poznań, adod@amu.edu.pl, ORCID: https://orcid.org/0000-0002-4726-5669. 


\section{Wprowadzenie}

Już samo tytułowe zestawienie pojęć kanon i resentyment implikuje szereg pytań: Dlaczego dziś zerwaliśmy z kanonem? Skąd się bierze współczesny resentyment czytelnika? Czy rozeszły się drogi prawdy i piękna? Czy mamy po prostu za dużo możliwości, za duży wybór tekstów? Otaczający nas świat jest całkowicie upolityczniony, staliśmy się populacją przede wszystkim unikającą przeciążenia informacją. Według Jeana Baudrillarda żyjemy w rzeczywistości, która jest prawdziwsza od siebie samej, jest swoim własnym simulacrum; teksty (zawierające pamięć o kulturze) niczego nie zmieniają, bo nie potrafimy już selekcjonować informacji. Znajdujemy się w takim punkcie historii, gdzie mimetyczny układ przyciągania-odpychania, będący według René Girarda „podstawą wszystkich patologii resentymentu” (Girard, 2018: 75), osiągnął punkt niezróżnicowania. Obserwowanie siebie w kontekście innych ludzi, porównywanie przedmiotów, obiektów czy dzieł, przestało być twórcze. Zatraciliśmy społeczne i kulturowe punkty odniesienia. W sztuce zwyciężyła symulacja sztuki, dokonywana w sposób bardzo podstępny, gdy sprawność warsztatu i opanowanie najnowszych technik wyrazu aspiruje do wyrażania prawdy o świecie. Tymczasem sztuka nigdy nie wyraża wszystkiego, a nadto powoduje raczej początkową dezorientację i niezaspokojenie odbiorcy, który często nie rozumie współczesnych mu arcydzieł i niekiedy musi dojrzewać do nich przez lata.

Pojęcie kanon będziemy rozumieć w zależności od tego, jakiego pola dotyczy. Najbardziej kojarzy się ono ze sztuką, gdzie funkcjonuje jako zespół wzorców, reguł i metod wytwarzania obowiązujących w danym okresie kultury w odniesieniu do form artystycznego wyrazu na określonym obszarze geograficznym i kulturowym. Wiąże się z zagadnieniami proporcji, wyraża poglądy estetyczne panujące w danym okresie. Mamy więc trzy pola pojęciowe dotyczące tła potrzebnego dla rozważań nad kanonem: kultura, czas i przestrzeń (każdemu z nich poświęcę dwa rozdziały. Nowe doświadczenia przestrzeni omawiam w tych zatytułowanych: Zglobalizowana przestrzeń i „Witamy na pustyni Rzeczywistego”, natomiast rozdziały $W$ poszukiwaniu wiecznej doczesności i Czas resentymentu mniej utalentowanych koncentrują nas na doświadczeniu czasu. O kulturze najwięcej mówią rozdziały Kultura złudzeń i Nieprzyjemność kultury). We wszystkich tych sferach zostały zachwiane proporcje, dlatego trzeba je omówić niejako oddzielnie. 


\section{Zglobalizowana przestrzeń}

Paradoks odczuwania współczesnej przestrzeni zglobalizowanego świata polega na tym, że żyjemy jakby poza nią albo przynajmniej w innej przestrzeni niż ta, o której snujemy od wieków refleksję. Jest to zupełnie nowy, jeszcze słabo opisany fenomen kulturowy. Nie chodzi tu tylko o nasilenie przepływu dóbr, kapitałów i siły roboczej w skali ogólnoświatowej, co odbija się na doświadczeniu przestrzeni, ale o rewolucję kulturową, która dokonała się pod koniec XX wieku wraz z upowszechnionym dostępem do sieci. Globalizacja ma przede wszystkim wymiar sieciowy, a przez to dopiero społeczny i kulturowy. Niepokojące jest pojęcie „ładu światowego” czy „rządu światowego”, kojarzone z bezosobowymi strukturami. Rozwój systemów społecznych zabiera jednostce nie tylko odpowiedzialność współudziału w tworzeniu kultury, ale w ogóle miejsca, gdzie mogłaby zaznaczyć jakikolwiek swój wkład. Globalizacja tworzy nowe terytorium, jednolite i niezróżnicowane, możliwe do ilościowego ujęcia, ale poza kulturą (co może pozostać dla nie-humanistów niewidoczne) i rzeczywistymi relacjami międzyludzkimi. Na przykład uniwersytety są dziś coraz bardziej „sparametryzowane”, pracę badawczą wycenia się za pomocą punktów, bez względu na jej wartość jakościową.

Michel Foucault używa terminu heterotopia (francuskie: hétérotopie) na opisanie przestrzeni, która nie stanowi już tradycyjnie rozumianych miejsc (Foucault, 2009). Heterotopia jest fizyczną reprezentacją lub przybliżeniem utopii albo równoległej przestrzeni, która daje się określić instytucjonalnie (weźmy dla przykładu przestrzeń więzienia i szpitala), ale dąży do oczyszczenia z definiujących ją niegdyś obiektów i ciał, aby siebie na nowo zdefiniować (więźniowie mają jak najszybciej wyjść na wolność, ponieważ nie wiadomo, jak ich dzisiaj karać, chorzy mają jak najszybciej wyjść ze szpitala, wcześniej tak są diagnozowani, żeby na przykład jak najszybciej wykonać zabieg i skrócić do minimum czas pobytu w klinice). Foucault wyjaśnia związek utopii i heterotopii za pomocą metafory lustra: odzwierciedlony obraz jest miejscem nierealnym, wirtualnym, które pozwala zobaczyć własną widoczność. Heterotopia jest jednocześnie absolutnie realna, powiązana z otaczającą ją rzeczywistą przestrzenią, i absolutnie nierealna, tworząca wirtualny obraz samej siebie. Jej multilokalność polega na tym, że jako miejsce jest doświadczana w wielu wymiarach, których często nie rozumiemy, nie odczytujemy. Pozostaje nam tylko doświadczenie przyjemnej dziwności, jak w galerii handlowej, która wydaje się zawierać wszystkie miejsca, jakich do życia potrzebujemy, pojawiają się w niej kościoły 
i szkoły, na razie na przykład szkoły tańca, lecz tylko kwestią czasu jest, aż pojawiać się tam zaczną uniwersytety. Heterotopia może być pojedynczym rzeczywistym miejscem, które zestawia kilka przestrzeni, przez to oddala nas od zapotrzebowania na nią, samą w sobie przestrzeń. Co najwyżej, jej struktura symuluje wolność poruszania się w niej i działania. Tymczasem jest ona przestrzenią dysfunkcji, nadaje się właściwie tylko do konsumpcji pustego czasu.

Kultura uwalnia się od swoich własnych miejsc, nie potrzebuje ich na przykład dla odpowiednich fenomenów, jak: religia - kościół, sztuka - galeria sztuki, filozofia - szkoła, sport - stadion, hala sportowa, śmierć - cmentarz, zdrowie - szpital itd. Lekarstwem na jej heteronomiczność jest tylko po rewolucji globalistycznej propozycja jej dodatkowego rozchwiania, zdecentralizowania, rozproszenia wartości czy idei (Doda-Wyszyńska, 2019). Wszystko oczywiście w interesie nas, konsumentów, których trzeba chronić, albo raczej chronić ich konsumpcyjny profil.

W nowoczesnych państwach najważniejszą rolę odgrywa ekonomia polityczna oparta na mechanizmach bezpieczeństwa, a nie refleksja nad kulturą. Poczucie szczęścia daje przede wszystkim zaspokojenie pierwszej w hierarchii ludzkich potrzeb: bezpieczeństwa. Państwa zapewniają nam je przede wszystkim w domyśle: w dążeniu, drodze do szczęścia. Wmawia się nam, że gdy jesteśmy bezpieczni (zabezpieczeni), to jesteśmy szczęśliwi. Dodatkowo, odkąd współczesne rządzenie podporządkowane zostało określonej liberalnej racjonalności, której miarą podstawową jest efektywność, a przestrzenią orzekania prawdy stał się rynek, humanistyczna refleksja nad kulturą zeszła nawet z poziomu politycznego, odwołującego się do wiedzy, na niższy, bardziej elementarny, dotyczący zaspokajania podstawowych potrzeb. Globalizacja tak zunifikowała wielokulturowość, że sprowadziła kulturę do stałych animalnych. Na całym globie ludzie podobnie jedzą, ubierają się, czytają te same instrukcje obsługi urządzeń (są to jedyne teksty tłumaczone na wszystkie języki świata), stosują te same leki itd.

Jedyną miarą efektywności systemu zarządzania, a jednocześnie przestrzenią orzekania prawdy o stanie populacji, jest rynek, a dawna (wymagająca przede wszystkim czasu na czytanie) humanistyka staje się na tyle odległa, że trudno ją włączyć w namysł nad funkcjonowaniem współczesnego człowieka (Doda-Wyszyńska, 2019).

Jean Baudrillard stwierdza, że uwalniając świat od humanistycznie rozważanej prawdy, uwalnia się go również od wszelkich pozorów, „staje się on prawdziwym uniwersum, uniwersum zintegrowanej rzeczywistości” (Baudrillard, 2006: 15). Zintegrowana rzeczywistość to rzeczywistość banalna, uniwersum faktów, które nie potrzebują nawet uznania za prawdziwe. 
Świat stał się tak rzeczywisty, że tę rzeczywistość można jedynie znieść kosztem wiecznego zaprzeczenia. „To nie jest świat” po „to nie jest fajka”. Dokonane przez Magritte’a surrealistyczne zaprzeczenie samej oczywistości - ów podwójny ruch, z jednej strony, absolutnej i definitywnej oczywistości świata oraz, z drugiej, radykalne zanegowanie tejże oczywistości - panuje nad trajektorią współczesnej sztuki, lecz nie tylko jej, ale również wszystkich naszych głębszych percepcji, wszystkich naszych ujęć świata. (Baudrillard, 2006: 15-16)

Przez brak transcendencji rzeczy są tylko tym, czym są, utraciły wszelką iluzyjność, a więc nie trzeba już ich nawet komentować. Jedynym zadaniem dla współczesnego „humanisty” jest oczyszczanie się ze złudzeń, a więc i z nadmiaru tekstów. Nie trzeba już ich porządkować, bo nadmiar likwiduje się w zarodku, najpierw poprzez streszczenia, a potem natychmiastowe podsumowanie. Rolę interpretacji i komentarza zastąpiły te dwa kroki: streszczenie i redukcja (na przykład poprzez zestawienia i uogólnienia: Kant mówił to samo co Arystoteles, że rzeczywistość nie jest idealna, a Proust jest podobny do Manna - obaj piszą o chorej arystokracji).

Coraz bardziej obce staje się pojęcie kanonu. Śledząc jego historię od początku XIX wieku, zauważymy, że staje się on zdecydowanie nietrwały. Wynika to z faktu, jak zauważył Niklas Luhmann, że w XIX wieku w sztuce (zwłaszcza w malarstwie) trwale rozdzieliły się piękno i prawda. Gdy salonowe malarstwo zrezygnowało z przedstawiania rzeczywistości na rzecz jej upiększania, sztuka przejęła rolę głównie dekoracyjną. Sztuka XX wieku natomiast próbuje znów postawić na wartość prawdy, lecz traci piękno. Ten XX-wieczny przełom wiążemy z Marcelem Duchampem. Jego Suszarka do butelek to całkowita negacja aspiracji do piękna. Jeśli więc już w XVII wieku została przełamana grecka aspiracja do piękna, z jej idealną proporcją i ludzkim modułem, to u Duchampa przełamaniu uległa wszelka aspiracja do piękna. Luhmann zadał pytanie: czy w takim razie ,jednostronny akces całej współczesnej sztuki do prawdy przeciw pięknu jest jeszcze do utrzymania?” (Luhmann, 2016: 46). Czy prawda nie jest tylko pustą przykrywką, alibi dla artystów sprowadzających dyskusję na poziom wewnątrzartystyczny?

\section{„Witamy na pustyni Rzeczywistego!"}

Może z marazmu wyrwą nas rozważania nad kanonem? Czyli nad tym, co kojarzy się z jakąś bazą, podstawą kultury? Najstarszy i najdłużej obowiązujący w kulturze był kanon sztuki starożytnego Egiptu. Miał on znaczenie religijne i polityczne, określał ściśle sposób obrazowania człowieka 
zależnie od hierarchii społecznej. I chociaż ewoluował na przestrzeni trzech tysięcy lat, do końca pozostawał przy swoich podstawowych założeniach. Już choćby na tym przykładzie widać, że kanon to nie tylko moduł, przyjęta zasada, wzór, reguła, norma, ale również narzędzie selekcji tekstów kultury, które pozwala odróżnić to, co wartościowe, od bezwartościowego. Ale trzeba nauczyć się nim posługiwać, a to wymaga dużego wysiłku zapoznawania się z wieloma tekstami kultury.

Uważam, że w tak zwanej drugiej połowie życia każdy powinien mieć swój własny kanon tekstów, a wcześniej, zwłaszcza w procesie edukacji, powinien zaufać mądrzejszym, lepiej wykształconym i bardziej doświadczonym, i nauczyć się korzystać z kanonów autorytetów. No tak, ale gdzie są dziś autorytety i kogo obchodzi postulatywna „powinność”? W czasach, gdy zakłada się równouprawnienie doświadczeń ludzi młodych i starych, rodziców i dzieci, nauczycieli i uczniów, nie ma miejsca na autorytety. Panuje pogląd, że starsi nawet mają obowiązek uczyć się od młodszych, ponieważ młodzi szybciej przyswajają nowoczesne technologie.

Paradoks nieprzekładalności osobistego doświadczenia na tekst (brak kanonu tekstów i przestrzeni, aby je komentować) wyzwala to, co ogólnie nazywa się kryzysem autorytetu. Autorytetem stają się ludzie elastyczni, a nie doświadczeni, zwłaszcza w interpretacji tekstów. Tym bardziej, że wszystko jest dzisiaj logiczne, jak powie Baudrillard, zwłaszcza w procesie oczyszczania nas ze wszelkich złudzeń nie widać końca. „Witamy na pustyni Rzeczywistego" - napisał francuski socjolog (Baudrillard, 2006: 16). Gdy jednak „rzeczywistość osiągnie masę krytyczną, spontanicznie zniszczy samą siebie” (s. 16), ustąpi wirtualności. Wirtualne rozumieć należy, zdaniem Baudrillarda, ,jako swego rodzaju wirusowy, samoniszczący się czynnik” (s. 16). Dominująca dzisiaj metafora sieci jako doskonałego połączenia wszystkich ze wszystkimi, z ujęciem wirtualności jako funkcji szybkiego osiągania virtus - cnoty sprawności, skutecznie pozbawia nas czasochłonnej potrzeby czytania tekstów dłuższych niż powiedzmy 300 znaków. Moc jest dzisiaj odpowiednikiem cnoty, a nie praca, zwłaszcza tak zwana „praca na tekście” czy jakieś abstrakcyjne wartości, które trzeba przemyśleć. Brakuje do tego przestrzeni. Mit mocy bazuje na fascynacji samym medium, na przykład medium sieci, które likwiduje rzeczywistą przestrzeń. Wirtualność zamienia wszystkie wartości w jedną - skuteczność, a tu już rządzi magiczna zasada podobne przez podobne (Doda-Wyszyńska, 2016). W naszej zglobalizowanej przestrzeni królują szybkie zestawienia i streszczenia tekstów.

Zdaniem Luhmanna stary problem z kanonem polega nie na wyznaczeniu tego, kto jest jego twórcą, bo właściwie każdy znamienitszy twórca tworzyć 
może nowe kanony, ale tego, kogo uzna się ostatecznie za twórcę kanonicznego. Kanon zależy od nas, czytelników, odbiorców, interpretatorów, od nas zależy, kogo uznamy za na tyle sprawnego obserwatora rzeczywistości, że jego zapisaną w dziele obserwację nazwiemy kanoniczną, czyli selektywną dla naszej obserwacji świata, dającą nam narzędzia do jej problematyzacji. Obserwowanie

[...] rodzi różnicę, która stwarza pewne otoczenie. Obserwator dystansuje się. Wszelka wszakże obserwacja świata jest możliwa tylko jako obserwacja w świecie, a ostatecznie: jako obserwacja obserwatorów. Chodzi o to, jaką robi różnicę, gdy świat jest obserwowany - tego zaś nie można obserwować w świecie, lecz tylko u obserwatorów. (Luhmann, 2016: 174)

Dzieło kanoniczne pozwala obserwować świat z dystansu umożliwiającego jego rozumienie i zmianę na lepsze. Ale my dziś nie potrzebujemy dodatkowego dystansu do świata, który stał się dystansem samym w sobie, zwirtualizowaną pustynią.

Artysta ma odtwarzać, zdaniem Luhmanna „sposób, w jaki funkcjonuje postrzeżenie” (Luhmann, 2016: 175), czyli widzi on coś, czego inni nie widzą, nową perspektywę, niezaanektowaną przestrzeń. Współczesna sztuka, zdaniem Luhmanna, poszukuje zupełnie innego rodzaju prowokowania odbiorcy, „zabiega o to, by sama była obserwowana jako obserwator. Szuka porozumienia we wzajemnym obserwowaniu obserwowania” (s. 175). Ale to za mało, nie wystarcza, aby dzieło stało się kanoniczne, żeby domagało się aktualizowania komentarzy na swój temat. Gest Duchampa nie wymaga żadnej aktualizacji, spełnił swój cel; dla wielu było nim zabójstwo sztuki. Bardziej subtelnie można go określić: ukazał niemoc sztuki jako komentarza do rzeczywistości. Gdy się obserwuje artystów w działaniu, pisze Luhmann, widać, że trzymają się oni swoich środków wyrazu, ale już od XIX wieku środki są celem dla siebie. Schemat myślowy celu i środka został „wciągnięty w wir reorientacji” (s. 175). Środków nie uznaje się już za narzędzia, nie stosuje się według reguł ani nawet programów. „Upada nawet rozróżnienie celu i środka” (s. 175). Do czego to w konsekwencji prowadzi? Do zaniku refleksji nad tym, czym jest prawda i piękno, czym różnią się od siebie te wartości, refleksji opartej na wysiłku wyławiania sztuki z obszaru nie-sztuki, anty-sztuki, kiczu, wartości z nie-wartości. Zaczyna brakować kultury samej w sobie, z podstawowym jej mechanizmem, tak zwaną przez Jurija Łotmana granicą przepuszczającą nie-teksty w obręb tekstów kultury, w obręb tego, co znaczące.

Łotmanowskie ujęcie kultury jako semiosfery wiąże się z określoną jednorodnością oraz indywidualnością; przede wszystkim jest ona odgraniczona 
od otaczającej ją przestrzeni zewnętrznej. Stąd z kolei wypływa fundamentalne znaczenie pojęcia granicy semiosfery. Stanowi ona swoisty filtr, urządzenie selektywne przepuszczające teksty z innych obszarów kulturowych oraz nie-teksty. Pełni funkcję „wąskiego gardła”, przez które muszą się przecisnąć komunikaty z zewnątrz, by stać się faktem danej kultury. W taki sposób cudze staje się swoim, zewnętrzne - wewnętrznym, nie-tekst - tekstem. Granica ma zazwyczaj abstrakcyjny charakter, choć czasami przebiega w realnej przestrzeni. Wewnętrzną organizację semiosfery cechuje daleko posunięta strukturalna nierównomierność (Łotman, 2008: 30). Przede wszystkim rozwój kultury wymaga nierównomierności przestrzennej, czyli przestrzeni o większym i mniejszym znaczeniu, przestrzeni, do której dostęp jest utrudniony. Dzieło artystyczne miało stanowić taką odgraniczoną przestrzeń, z utrudnionym dostępem, ponieważ jest „przepracowaniem przypadku w zależną od przypadku konieczność” (Luhmann, 2016: 178). Odczytanie konieczności wymaga wielkiej pracy umysłowej, o czym chyba najdobitniej, we wszystkich swoich dziełach, pisał filozof amerykański Charles Sanders Peirce. Do wyczytania konieczności z dzieła sztuki potrzebujemy „dyscyplinującego obserwowania” (Luhmann, 2016: 178), jakiego kiedyś uczyło obcowanie ze sztuką i znaczącymi tekstami kultury (kanon).

Nowa przestrzeń doświadczenia współczesnego człowieka ma być przede wszystkim jasna, łatwa w obsłudze, dlatego dominują w niej instrukcje, bez pytań o prawdę. Na osłodę, dla niezadowolonych humanistów, mamy co najwyżej przestrzeń upiększoną, czysto estetyczną, w której czci się moc, moc obrazów przede wszystkim, odbitych w sieciowych ekranach.

\section{W poszukiwaniu wiecznej doczesności}

Zanim pojawi się problem polityki czy kultury, współczesna populacja jest tresowana (poprzez media) do bardzo określonego odbioru rzeczywistości, w której żyje. Dominującą dziś formą racjonalności jest ta ściśle związana z urządzaniem życia masom, które domagają się co najwyżej odpowiedzi na jakieś konkretne niedobory życiowe, a nie nowych interpretacji tekstów kultury. Nikt nie ma na to (może poza sztucznie oddzielonymi od świata w przestrzeniach uniwersytetów akademikami) czasu.

Mam wrażenie, że we współczesności dominującą formą przeżywania jest uwieczniona, uwznioślona doczesność. Utraciliśmy potrzebę, na którą odpowiadała sztuka - wyznaczania pozadoczesnej, niezależnej od codzienności perspektywy życia. Zdaniem Luhmanna można ująć sztukę jako 
uwidacznianie niewidocznego, zwłaszcza naukę rozróżniania gry form, bardzo cenną życiowo, ponieważ „każda forma realizuje paradoks rozwiązania nierozwiązalnego problemu” (Luhmann, 2016: 182). Każde użycie formy, która potem podlegać będzie deszyfryzacji, wymaga uwagi zarówno ze strony twórcy, jak i odbiorcy. Obserwowanie, którego uczy nas sztuka, to umiejętność trzymania się tego, co odróżnione. To jakby realizacja funkcji ślepej plamki leżącej u podłoża widzenia. To jednak, że w samym odbiorze sztuki tkwi jakiś problem, zostaje odkryte dopiero wtedy, gdy obserwowanie obserwowania samo staje się tematem dzieła. Świat w ujęciu Luhmanna to ślepa plamka jego samoobserwacji (s. 183).

Moim zdaniem najlepiej umiejętność odróżniania sztuki od reszty świata dookreśla pojęcie idiolekt, opisane przez Umberto Eco, przeniesione na grunt estetyczny. Koncepcja ta zawiera opis szczególnego przedmiotu estetycznego, jaki stanowi dzieło sztuki, które utrwala specyficzną funkcję komunikatu estetycznego: niejasność + zwrotność; „,u podstaw wszystkich poziomów jego organizacji leży ten sam schemat strukturalny” (Eco, 1996: 85), który musimy umieć wyczytać. Jedynie w dziele sztuki niejasność może mieć pozytywny wymiar, służy interpretacji, a nie dążeniu do natychmiastowego jej wyeliminowania. We wszystkich innych rodzajach komunikatów niejasność odgrywa negatywną rolę. Czyli, jeśli chcemy wydobyć (opisać) idiolekt jakiegoś zjawiska w sztuce, musimy umieć wywieźć wszystkie istotne (czyniące go niezwykłym) treści i historie z samej formy dzieła. W tym sensie: reguła utworu stanowi jego idiolekt. Idiolekt to inaczej język osobniczy (z gr. idios „własny, swoisty” + leksis „mowa”), forma mowy charakterystyczna dla danego użytkownika języka w danym okresie jego rozwoju; wyznacza on tak zwany gust stylistyczny. W miarę komplikowania się komunikatu estetycznego pojawia się w nim samozwrotność (s. 87), czyli na każdym kolejnym poziomie analizy formalnej „rozwiązania układają się w analogiczny system relacji” (s. 85). Aby komunikat estetyczny przerodził się w idiolekt, gra różnic na poziomie formalnym (na przykład rytmicznym) odpowiadać musi grze opozycji na poziomie konotowanych znaczeń, także grze poruszanych przez formę artystyczną idei itd. Jest to inaczej opis jedności formy i treści w udanym utworze artystycznym. Idiolekt utworu rodzi „naśladownictwo, manierę, zwyczaj stylistyczny, a wreszcie nowe normy” (s. 85-86), o czym nas uczy cała historia sztuki i kultury. Idiolekt to też schemat strukturalny przyświecający wszystkim częściom utworu, co umożliwia wzięcie w ramy jego przedstawieniowej niejasności. Wyrabia w nas gust. Mogłoby się wydawać, że pojęcie to kłóci się z niejasnością komunikatu estetycznego, ale to bardzo powierzchowne rozumienie. Idiolekt organizuje 
kontekst twórczości i odbioru sztuki, nieustannie przekształca swoje własne denotacje w konotacje, w swoje własne znaczenia, w oznaczniki innych znaczeń. Arcydzieło sztuki porządkuje świat, jak chciała hermeneutyka, wokół siebie, wokół przeżycia, które generuje w odbiorcy, i dalej, pozwala lepiej rozumieć nie tylko inne dzieła sztuki, ale przede wszystkim zewnętrzny świat. W tym kontekście koncepcja idiolektu Eco domyka hermeneutyczny ideał rozumienia w tak zwanych naukach humanistycznych. No tak, ale to jest pewien ideał - powie współczesny odbiorca. Tak zwane kanony tekstów tworzone są w tym celu, żeby ideał wcielić w teksty stanowiące autentyczną zapisaną mądrość czasu, a potem, żeby móc z tej mądrości w dowolnym czasie skorzystać. No tak, ale dziś nie ma czasu na świadomy odbiór tekstów, na wypracowywanie ich rozumienia.

Kanon tekstów powinna wyznaczać lektura, w której doznajemy szczególnego przeżycia, zadziwienia i zdumienia zamiast spełnienia oczekiwań, jak napisze Harold Bloom. Mimo wszystko za najbardziej kanonicznego dla literatury Bloom uważa Szekspira, który często wywołuje odwrotne wrażenie: „zadomawia nas w świecie na zewnątrz, obcym, za granicą. Jego moc asymilacji i kontaminacji jest unikalna i stanowi ciągłe wyzwanie dla inscenizatorów i literaturoznawców” (Bloom, 2019: 13). Dziwność i doniosłość Szekspira wynika z jego lekkości, ten kanoniczny autor wydaje się mało wymagający, lektura Szekspira po prostu „wciąga”. „Wraz z Dantem znalazł się w centrum kanonu, ponieważ obaj przewyższają innych zachodnich pisarzy poznawczą wnikliwością, energią językową i siłą inwencji” (s. 57). Szekspir przede wszystkim „przewyższa wszystkich we wskazywaniu psychologii zmienności” (s. 61).

Bloom proponuje swój kanon książek dla świata Zachodu, dla czytelnika współczesnego z końca XX wieku. Wyselekcjonował ze względu na wzniosłość i reprezentatywność dwadzieścia sześć postaci i próbował bezpośrednio zmierzyć się z ich wybitnością, pytając, co czyni danego autora i dane dzieła kanonicznymi. Zwykle odpowiedź brzmiała: dziwność, typ oryginalności, który nie daje się łatwo oswoić albo który tak nas oswaja, że przestajemy postrzegać go jako dziwny. Powołując się na najlepszego, zdaniem Blooma, współczesnego angielskiego literaturoznawcę sir Franka Kermodego, wypowiada jego ustami najdobitniejsze ostrzeżenie w kwestii losów kanonu, to znaczy przede wszystkim losu Szekspira. Kanony paradoksalnie negują odróżnienie wiedzy od opinii, stanowią narzędzie przetrwania stworzone jako odporne na upływ czasu, i chociaż są jako takie dekonstruowalne (s. 14), tworzą w nas narzędzie myślenia, odniesienie problemowe, utrwalone przeżycie, jak chciała hermeneutyka. 
Współczesność nie lubi kanonów, bo nie lubi zapisu dziwności. Świat jest zbyt skomplikowany, żeby jeszcze o tym czytać... - tak odpowiadają nawet humaniści, którzy, owszem, piszą (bo muszą), ale już nie czytają. Praktycznie biorąc, „ekspansja kanonu” zawierała także, zdaniem Blooma, jego destrukcję. Kanon chce dziś obejmować raczej pisarzy oferujących niewiele więcej prócz resentymentu, w którym nie ma dziwności ani oryginalności, za to czytelny jest lęk przed wpływem. Wieczna doczesność niezobowiązujących kanonów, złożonych nawet z książek, które się wprawdzie czytało, ale bez konsekwencji dla naszego życia, bez przemyślenia, bez interpretacji, to czas tak zwanej „współczesnej kultury”, która z kulturą ujętą tradycyjnie ma coraz mniej wspólnego.

\section{Czas resentymentu mniej utalentowanych}

Każdy tak zwany „silny” utwór literacki twórczo, czyli źle, odczytuje, i dlatego dezinterpretuje wcześniejszy tekst lub teksty - stwierdził Bloom. Kanoniczny pisarz może, choć nie musi, zinternalizować lęk czyjegoś dzieła, może być całkowicie pod jego wpływem, a i tak stworzy coś oryginalnego (Bloom, 2019). „Lęk przed wpływem paraliżuje słabsze talenty, lecz pobudza kanonicznego geniusza” (s. 21). Bloom pisze o resentymencie współczesnych humanistów, którzy dążą do oryginalności, a nie do prawdy, dlatego pomijają dzieła kanoniczne, nie potrafią się na nich uczyć.

Kanon uczy przede wszystkim dobrych wyborów, nie tylko wyborów tekstów. To może być najważniejsza misja humanistów: pokazywać kanon, kanony, i uczyć wybierać własny, aby następnie kształtować myślenie i dokonywanie wyborów życiowych, łączących estetykę z etyką. Aksjologia (nauka o wartościach) pierwotnie łączyła estetykę z etyką, o czym dzisiaj łatwo się zapomina. Sztuka miała za zadanie uczyć nas żyć, ukazywać doświadczenie, którego nie zdążymy realnie przeżyć, ale możemy uczyć się na błędach innych, zwłaszcza postaci fikcyjnych. I chociaż nie można, co podkreśla Bloom, sprowadzać estetyki do ideologii ani nawet do metafizyki, to wypowiedź ta dotyczy tylko nieprzekładalności doświadczenia, a nie nieprzekładalności sztuki na filozofię. Estetyka, wyzwolona dzisiaj od filozofii, często staje się narzędziem polityki. Każdy tekst, „każdy język idzie na służbę władzy”, jak mówi Roland Barthes (Barthes, 1979: 11). Może pójść... Ale literatura ma moc uwolnienia od tego zagrożenia, przezwycięża nawet filozofię, nie daje się sprowadzić do tak zwanych nauk humanistycznych. 
Sztuka zawsze próbowała zachować swoją autonomię, choć dzisiaj jest to wyjątkowo trudne. Tylko literaturze wciąż się to udaje, mimo że przeprowadzono na nią atak „pod sztandarami nowej wielokulturowości” (Bloom, 2019: 28). Obserwujemy nawet pewien rodzaj lęku przed sztuką i jej kanonem. Bloom odwołuje się tu do Nietzscheańskiego pojęcia resentymentu - specyficznej zazdrości, która nie walczy o przejęcie jakiegoś dobra od innego, tylko hoduje nieuzasadnioną zawiść wynikającą z duchowego lenistwa. Drażni nas to, czego nie potrafimy zrozumieć. Bo właściwie dziś od literatury, i ogólnie sztuki, już się niczego wielkiego nie oczekuje. Co najwyżej może ona być sztandarem jakiejś ideologii, buntu czy sprzeciwu.

Max Scheler chyba najlepiej dookreślił pojęcie resentymentu, które u Friedricha Nietzschego rozlewa się na każdą ludzką aktywność. Po pierwsze, chodzi tu o pewną wtórną emocję, a wtórne emocje są zjawiskiem powszechnym. Najlepszym kryterium odróżnienia emocji wtórnej od pierwotnej jest jej siła i nieadekwatność. Emocja pierwotna, nawet jeżeli jest silna, najczęściej nie jest długotrwała, trwa tyle, ile bodziec ją wywołujący, i jest do niego adekwatna. Po drugie, resentyment to „powtarzane przeżywanie i odtwarzanie określonej emocjonalnej reakcji na innego, która sprawia, że owa emocja pogłębia się i zakorzenia w centrum osobowości, a wraz z tym oddala się od sfery wyrazu i działania danej osoby” (Scheler, 2008: 9-10).

Sama przykrość z powodu tego, że ktoś inny ma dobro, o które zabiegamy, którego pragniemy, nie jest wystarczająca, aby przerodziła się w nas w resentyment, czyli zahamowaną, wtórną zazdrość. Taka przykrość (zwana niesłusznie zazdrością) może motywować do pozyskania dobra, którego nam brakuje, na przykład do uczciwej pracy. Prawdziwa zazdrość resentymentu pojawia się dopiero wtedy, gdy zawodzi próba podjęcia działań w kierunku zdobycia upragnionego dobra i pojawia się poczucie niemocy, resentyment właśnie. Dlatego jest „błędem zaliczanie zazdrości do sił napędowych rozwoju cywilizacji obok innych motywacji psychicznych (żądza posiadania, władzy, próżność)” (s. 25). Prawdziwa grzeszna zazdrość (resentyment) nie wzmaga woli zdobywania, lecz ją osłabia. Znów jednak prowadzi do resentymentu dopiero tam i tym bardziej tam, gdzie chodzi o wartości i dobra niejako z natury nieosiągalne i ulokowane w porównywaniu się z innymi, takie jak wykształcenie, które nie tyle jest potwierdzone dyplomem i odpowiednim poziomem życia, co wpływa na całokształt indywidualnego doświadczenia. Pięknie przykład resentymentu wykształconego lekarza wobec tak zwanego znachora jest ukazany w powieści Tadeusza Dołęgi-Mostowicza Znachor i zrealizowanych na jej podstawie filmach. Lekarz nie widzi, że tytułowy znachor poradził sobie z chorobami, które on uznał 
za nieuleczalne i śmiertelne, ponieważ ma wykształcenie, które każe mu wierzyć w trafność swoich osądów mimo faktów stojących w sprzeczności $\mathrm{z}$ jego diagnozami.

Zazdrość najbardziej bezsilna jest zarazem zazdrością najstraszniejszą, resentymentem właśnie. Ciągłe przeżywanie na nowo i odtwarzanie owej emocji bardzo różni się od czysto intelektualnego wspominania. Emocja ta nie wyzwala działania, lecz je hamuje, ostatecznie hamuje nawet samą emocję. Friedrich Nietzsche resentyment ustanowił źródłem większości sądów o wartościach, Scheler nie idzie tak daleko, ale podkreśla, że kiedy resentyment staje „w centrum osobowości”, mamy do czynienia z osobowością wrogą, zwłaszcza wobec zmian w myśleniu. Takie zmiany może powodować nieuprzedzona lektura znaczącego w kulturze tekstu.

Jako przykład prawdziwej eksplozji resentymentu Scheler podaje rewolucję francuską, ponieważ opierała się ona na stosunku zdeklasowanej szlachty (mieszczan) do szlachty i wszystkiego, co się wiązało z jej stylem życia. Wtedy to zrodziło się nowe poczucie równości zbuntowanych przeciw warstwie panującej, które przydało ostrości trwającemu do dziś, również związanemu z odbiorem sztuki, resentymentowi. Stąd największy ładunek resentymentu zawiera w sobie społeczeństwo, w którym polityczne i formalne społeczne równouprawnienie idzie w parze z bardzo dużymi różnicami pod względem faktycznej władzy, posiadania i wykształcenia. „Żądza zemsty przechodzi w resentyment, im bardziej przybiera postać trwałych stanów, ciągle odczuwanych jako «raniące» i niezależne od sił woli zranionego, im bardziej zranienie odbiera się jako wyrok losu” (s. 22).

Roland Barthes o klasie pełnej resentymentu, dążącej do wolności, między innymi od kanonów kultury, od humanizmu, pisał, że stanowi społeczeństwo anonimowe i nie chce być nazywana. Nowe mieszczaństwo nie chce być nijak nazywane, zwłaszcza nie chce być nazywane mieszczaństwem, to klasa/nie-klasa - idealny konsument mitu o potędze. Ideologia mieszczańska może wypełnić wszystko, napisze Barthes, i wyzbyć się swego imienia, „odrzucenie mieszczańskiego imienia jest właśnie ideologią mieszczańską” (Barthes, 2000: 276). Ta ideologia jest przede wszystkim ahistoryczna, ponieważ „ludzi nie wiąże z mitem relacja prawdy, ale relacja użyteczności” (s. 279). Barthes wyróżnia siedem podstawowych figur mitu, w których jest on odbierany jako prawda o rzeczywistości. Skoro mit, jak pisze Barthes, działa poprzez zestaw informacji, który hamuje ich przetwarzanie, to im mniej czasu potrzebujemy, żeby dokonać takiego zestawu, tym lepiej. Zestawy informacji są mityczne i przede wszystkim antykanoniczne, ponieważ ustalanie kanonów kultury zabiera sporo czasu. 


\section{Kultura złudzeń}

Znaczenie już definicyjnie wieloznacznego pojęcia kultury, tego najbardziej znaczącego tła humanizmu, wyraźnie zmieniły procesy globalizacji. Współczesne doświadczenie kultury nie tylko jest szczególnie zapośredniczone (mass media, ekrany, interfejsy, sieć itp.), ale przede wszystkim jest globalne. Doświadczamy innej niż nasi przodkowie przestrzeni, żyjemy w innym niż oni czasie. W sposób wymuszony jesteśmy przyzwyczajani od lat niemowlęcych do doświadczania globalnego systemu przymusu, jako po prostu urządzania nam życia, do takich, a nie innych zachowań, do takiego, a nie innego odbioru rzeczywistości. Jesteśmy już nie społeczeństwem, ale populacją. Podejmując problemy rządzenia populacją, humanistyka (z wszystkimi swoimi przejawami naukowymi: literaturoznawstwo, historia, filozofia, socjologia itd.) wikła się w wyjątkowo ciasne błędne koło, grożące całkowitą alienacją myślenia, zwłaszcza myślenia o kulturze.

Michel Foucault (2013) nie wahał się problemów związanych z ogólnym pojęciem humanizmu nazwać po prostu złudzeniami, a samego humanizmu największą iluzją kultury zachodniej, upolitycznioną iluzją wykorzystywaną dla podbudowy ideologii konsumpcji. Tak zwane nauki humanistyczne (czy społeczne) pozostawiają dziś człowieka samemu sobie, a zajmują się systemami, strukturami, ich kombinacjami, formami, ale zamiast modyfikować ich działanie, produkują chimery, które natychmiast stają się polityczne, służą systemowi kapitalistycznemu i ideologii technokratycznej postulującej naukę i technikę jako źródło wszystkich wartości, podporządkowując im cele i środki dla samodoskonalenia się człowieka (Doda-Wyszyńska, 2019).

Mit tak zwanej „kultury współczesnej” według Barthesa opiera się na działaniach porządkujących wiedzę i służących bezmyślności. Są one opisane przez siedem figur - metafor (ich kolejność nie ma znaczenia): szczepionka (polega na wyznaniu „małego” zła, aby zamaskować zło podstawowe, dużo większe), pozbawienie historii (historia wyparowuje, na przykład podkreśla się odwieczność instytucji zamiast jej umowność i zależność od uwarunkowań [historycznych]), identyfikacja (aby kogoś zrozumieć, musimy móc się z nim zidentyfikować, dlatego upraszcza się różnice kulturowe, sprowadza się je na przykład do różnicy gustów kulinarnych, a nie do rozwiązań społecznych typu możliwość zawarcia małżeństwa z nieletnią lub poligamii; nie mówi się różnicach, które powodują, że człowiek 
z innej kultury funkcjonuje jak barbarzyńca i na przykład niszczy naszą kulturę), tautologia (czyli definiowanie czegoś paradoksalnie przez brak definicji: „Teatr to teatr”; tautologia podkreślać ma zwłaszcza umowność jakichś tworów kulturowych, społecznych, instytucji, kanonów itd.), ani-anizm (to zestawianie przeciwieństw, żeby pokazać, że nie ma różnicy tam, gdzie język lub kultura ją wskazuje, na przykład powiedzenie, że człowiek wykształcony i niewykształcony tak samo odbiera świat, bo ma takie same potrzeby biologiczne), kwantyfikacja jakości (polega na „redukcji każdej jakości do relacji ilościowej”, wszystko można dziś obliczyć, wycenić i „wszystko można kupić”) i stwierdzenie. Ostatnią figurą wymienioną przez Barthesa jest stwierdzenie, bowiem „mit zmierza do przysłowia”, daje się wyrazić w postaci lekkostrawnej prawdy, na którą wszyscy się zgodzą. Przeważnie jest to jakiś banał, taki jak: Kanon jest ważny dla rozwoju kultury. Mityczne stwierdzenia pozostają oddzielone od możliwości ich sproblematyzowania i przede wszystkim wprowadzenia w życie. Pozostają często na poziomie postulatywnym (Barthes, 2000: 286-291).

W przeszłości, jak zauważa Scheler, zabezpieczeniem przed resentymentem (ujawniającym się u Barthesa poprzez różne mityczne figury) była myśl o danym przez Boga i naturę „miejscu”, w którym każdy czuje się „postawiony” i w którym ma wypełniać swoją konkretną powinność (Scheler, 2008: 31). Dzisiaj, w „systemie konkurencyjnym”, idee zadań i ich wartości kształtują się na podłożu woli, po odpadnięciu wszelkich pierwotnych ograniczeń. Indywidualna wola nie zna granic, co zmienia strukturę ujęcia wartości. Prowadzi do podstawowego ujęcia wszystkich rzeczy jako „towaru”.

Resentyment jest przede wszystkim złudzeniem co do wartości, co do ich przeżywania, bezpodstawną krytyką cudzych wartości, których przeżywania nawet nie potrafimy sobie wyobrazić. Schelerowski opis resentymentu pasuje do opisu Hermana Brocha postawy kiczowej, promującej nie tyle słabą sztukę, co, aksjologicznie rzecz ujmując, sztukę złą. Sztuka osiąga bowiem piękno nie w sposób bezpośredni. Jeśli artysta dąży do piękna, jest twórcą kiczu, nie zaś dzieła. Hasłem przewodnim artysty powinno być, według Brocha, „pracuj dobrze”, dobrze wykonuj swoją robotę, a piękno „spadnie w dłonie”, gdy szczęśliwie ukończysz dzieło (Broch, 1998: 113). Współczesny prosument to ktoś więcej niż konsument, ponieważ jest profesjonalistą. Twórca kiczu jest dziś przeważnie profesjonalistą. Współczesna kultura to przede wszystkim kultura profesjonalistów, ekspertów, specjalistów, zwłaszcza technicznych. Bo nie można być specjalistą w humanistyce. 
Określenie „prosument” to zbitka wyrazów: „producent” (lub „profesjonalista”) i „konsument”. Słowo stworzone przez Alvina Tofflera (1997: 43-45) opisuje niemożliwą do spełnienia potrzebę współczesnego uczestnika kultury, by mieć dostęp do całego procesu wytwarzania jakiegoś dobra i nawet moc wpływania na jego ostateczny kształt. Termin ten rozmywa dotychczasowe odróżnienie sfery produkcji od sfery konsumpcji i obejmuje czynności, które kreują wartości, prowadząc zarazem do wytworzenia produktu będącego przedmiotem konsumpcji. Czynności te stają się pasmem doświadczeń konsumenta skumulowanych wokół produktu. Prosument uczestniczy w procesie projektowania lub współprojektowania, lub też koprodukcji jakiegoś „dobra”, na przykład wypowiadając się na temat możliwości jego ulepszenia lub potrzeb z nim związanych, uczestniczy zatem w całym procesie kreowania jego wartości. Wydawać by się mogło, że osiągnęliśmy doskonałą harmonię tworzenia wartości związanych z konkretnymi „dobrami” (towarami), nowy rodzaj ładu społeczno-gospodarczo-politycznego - i jest to być może jedno z naszych największych złudzeń kulturowych.

Demokracja znacznie rozszerzyła swój zasięg, z politycznego na wszystkie dziedziny życia, włącznie z tak zwaną kulturą wysoką. W czasach, gdy prosumpcja objęła nowoczesne media i obejmuje powszechne uczestnictwo w procesie produkcji czy wytwarzania dóbr na wszystkich etapach, również na etapie interpretacji, aksjologia staje się pustą nauką o wartościach i wydaje się próbą ograniczania współcześnie rozumianej wolności. Wolność w wymiarze kulturowym regulować mają, owszem, „artyści”, ale zwolnieni z obowiązku podporządkowania się normom, na przykład formalnym, wolni od wpływu, mają dawać łatwy dostęp do swoich produkcji. Najlepiej, niech jeszcze sami tłumaczą, co chcieli powiedzieć przez swoje twory. Brak jest rytuałów, procesów wtajemniczenia.

\section{Nieprzyjemność kultury}

Kanon umożliwiał wtajemniczenie, to

[...] słowo pochodzenia religijnego, stał się wyborem spośród tekstów walczących ze sobą o przetrwanie, jakkolwiek rozumieć wybór: jako dokonywany przez dominujące grupy społeczne, instytucje kształcenia i tradycje krytyki literackiej, czy, jak ja zakładam, przez późnych autorów czujących się wybranymi przez określonych przodków. Niektórzy najnowsi zwolennicy akademickiego radykalizmu posuwają się do twierdzenia, że utwory dołączają do kanonu w wyniku udanych kampanii reklamowych i propagandowych. (Bloom, 2019: 30) 
Niebezpieczeństwem zagrażającym współczesnym kanonom jest zamiana ich w sztywny „ideał”. Wynika to z ucieczki od wymiaru estetycznego rozumianego na tle aksjologii. Bloom formułuje główną zasadę obecnej szkoły resentymentu: tak zwana wartość estetyczna stała się emanacją walki klas. Indywidualna jaźń jest jedyną metodą przeciwstawienia się temu i ,jedynym skupiskiem norm pojmowania wartości estetycznej” (s. 34), ale staje się ona czysto postulatywna, bowiem skoro definiuje się tylko przeciw społeczeństwu, w konflikcie klas społecznych i ekonomicznych, to gdzie ją poza konfliktem lokować?

„Oryginalność jest wielkim skandalem, którego resentyment nie potrafi strawić, a Szekspir pozostaje najbardziej oryginalnym pisarzem, jakiego kiedykolwiek poznamy” (s. 36). Za sprawą Szekspira cała silna oryginalność literacka staje się kanoniczna, ale już epoka oświecenia walczy z tak ujętym kanonem i kanonicznością.

Scheler stwierdzi, że filozofia epoki oświecenia doprowadziła do zastąpienia idei „przedmiotu” tym, co „powszechne” lub „powszechnie obowiązujące”. Wszyscy mają tworzyć „powszechnośc”, także w swoich ocenach wartościujących mają realizować ideał, którym ma się mierzyć pozytywne konkretne ukształtowanie kultury. Pojęcie „ogólnoludzkie” nabiera tu znaczenia najwyższej wartości (Scheler, 2008: 172). Pieczęcią tego procesu jest dumna kategoria ratio w swoim nowożytnym, pooświeceniowym ujęciu.

Choć bowiem „dobro” jako wartość wciąż powszechnie obowiązuje, nie można go zdefiniować jako maksymy nadającej się na powszechnie obowiązującą zasadę. Scheler podaje tu obrazowy przykład zaawansowanych matematyków: tak jak jedynie bardzo niewiele osób potrafi zrozumieć pewne matematyczne problemy i teorie, tak też może być w odniesieniu do rzeczy moralnych i religijnych. Kanon więc buduje elitarność kultury, nie jej egalitaryzm.

Dlatego „istoty o bogatszym uposażeniu poznawczym lub większej zdolności do odczuwania mogą przekazywać innej grupie przedmiotowe prawdy i wartości, dla których nie ma ona organu źródłowego poznania” (s. 173). W kwestii kanonu trzeba zdać się na tych, którzy więcej pracy włożyli w jego konstrukcję i interpretację; to był niegdyś podstawowy cel kształcenia na poziomie uniwersyteckim, ale ten czas już się skończył, odkąd idea uniwersalności zastąpiona została ideą doskonałości (w domyśle urzędniczej). O tym groźnym dla humanistyki zjawisku pisał Bill Readings (2017) w Uniwersytecie w ruinie. Uniwersytet podporządkowany systemowi wymiany (idea doskonałości) nie działa już jako „strażnik kultury”, a przyczyniły się do tego właśnie nauki o kulturze. Uprawiamy nauki o kulturze bez filozofii, 
bo to się opłaca, rynek wymaga od uniwersytetu określonej wiedzy, która uprawomocnia działania polityczne. W świecie naukowym dominują mody na nazwiska, teorie, koncepcje, pojęcia. Niektóre pojęcia, takie jak zarządzanie, media, systemy, wprost odwołują się do mechanizmów rynkowych. Odkąd instytucja uniwersytetu podporządkowana jest rynkowi, badaczowi kultury pozostaje intencjonalność schizofreniczna. Trzeba badać to, co generuje wzrost gospodarczy, co napędza rynek, a z drugiej strony - stawiać sobie pytanie, dokąd zmierza świat. Pewną pośrednią drogę wynaleźli kulturoznawcy, badając zjawiska niszowe, przemijające konstrukty kulturowe, fenomeny marginalne. Wiedza na ten temat może się okazać ważna, kluczowa nawet, ale te pola rozważań (zbieranie danych, analiza i interpretacja) powinny się spotkać, a coraz rzadziej do tego dochodzi. Coraz też częściej uzasadniany jest brak takiej potrzeby.

Współczesny ascetyzm (braku potrzeby interpretacji tekstów, braku zapotrzebowania na kanon) przejawia się w zażywaniu przyjemności, do którego odnosi się wszystko, co użyteczne, „rzeczy przyjemne zostają podporządkowane użytecznym” (Scheler, 2008: 181). Resentyment, występujący przeciw wyższej zdolności do zażywania przyjemności kulturowej, kreuje współczesnego człowieka na człowieka pracy i użyteczności. Człowiek taki przewartościowuje wyższą przyjemność i jej zażywanie w coś „złego”. Tworzy się nieskończenie skomplikowany mechanizm błędnego koła w produkcji tak zwanych rzeczy przyjemnych, która przekłada się na „pracę”, ponieważ jednak owa praca w służbie użyteczności wyrosła właśnie z mniejszej zdolności do zażywania przyjemności charakterystycznej dla arystokracji, zatem najciężej pracujący i dzięki temu dysponujący zewnętrznymi środkami do zażywania przyjemności najmniej mogą jej zażywać. Tymczasem grupom o bogatszym życiu wewnętrznym coraz bardziej brakuje środków (często po prostu czasu), jakich ich zdolność potrzebuje do skonsumowania wyższej przyjemności płynącej z lektury czy obcowania z dziełami sztuki. „Stąd rodzi się we współczesnej cywilizacji tendencja do takiego działania, by niezmierzone nagromadzenie wytworzonych przez nią przyjemnych rzeczy koniec końców nikomu nie służyło” (s. 182). Powstaje, zdaniem Schelera, pytanie bez odpowiedzi, filozoficzne pytanie „po co”. Po co wytwarzać dobra kulturowe, skoro typ człowieka, który się tym trudzi, nie może się cieszyć owocami swojej pracy, a ten, który środki posiada, nie potrzebuje dóbr kultury umożliwiających doświadczenie wyższej przyjemności, a nawet odrzuca ją ,jako «złe» delektowanie się z takim wysiłkiem wytworzonymi rzeczami” (s. 182).

Nadaje to współczesnej cywilizacji „groteskowy” wyraz, stwierdzi Scheler, narzuca jej nową formę ascezy od kultury. Dawna asceza służyła 
doświadczeniu przyjemności płynącemu z kultury. Należało potęgować zdolność do czerpania jej z najprostszych, wszędzie dostępnych rzeczy, nawet doświadczenie przyrody służyło doświadczeniu sztuki. Religijne nakazy cnoty dobrowolnego ubóstwa, posłuszeństwa, wstrzemięźliwości, podtrzymywały zdolność do kontemplacji świata i płynący z niej „stopień przyjemności, jaki słabsze życie może osiągnąć tylko dzięki większej ilości takich rzeczy” (s. 183). Rzecz użyteczna stanowiła kiedyś tylko środek pomocniczy zażywania przyjemności, a największą „zdolność do delektacji” miał ten, kto z minimum przyjemnych rzeczy potrafił czerpać więcej przyjemności niż ktoś inny z większej ich ilości. „Dawna asceza - świadomie lub nie - potęgowała zdolność do delektacji, a tym samym także życie” (s. 183). Współczesna asceza konsumpcji wykreowała ideał odwrotny, który pod względem etycznego sensu jest właśnie przeciwieństwem dawnego: „«ideał» minimum przyjemności przy maksimum rzeczy przyjemnych” (s. 183).

\section{Wnioski}

Dzisiaj humanista ma zupełnie nowe role, ponieważ zmieniła się nie tylko kultura, ale też czas i przestrzeń - podstawowe formy zmysłowości, które Immanuel Kant czyni naszym głównym punktem orientacji i polem dla myślenia o świecie. Filozof ten (w dużej mierze za Alexandrem Gottliebem Baumgartenem) bezpośrednio wiąże dziedzinę zmysłów z umysłem. Kantowskie czyste formy zmysłowości: czas i przestrzeń, stanowią schematy pozwalające przechodzić od pojęcia do figury albo od postaci do tła (Gestalt), pozwalają myśleć o świecie w sposób abstrakcyjny, tekstowy i go rozumieć w jakichś całościach, humanistycznie. Upraszczając Kantowską refleksję o formach zmysłowości, możemy powiedzieć, że czasowość organizuje doznania wewnętrzne, a przestrzenność doznania zewnętrzne. Myślimy o czasie i przestrzeni, jak gdyby były widocznymi cechami świata, ale to nasze formy zmysłowości narzucone światu, pewna abstrakcyjna zdolność zawarta już w zmysłowym odbiorze świata. Kant, wydobywając owe czyste formy zmysłowości: czas i przestrzeń, buduje miejsce podmiotu na przecięciu tych form. Schematyzm wyobraźni, którym posługuje się poznający podmiot, pozwala przemontowywać przedstawienie, czyli dokonywać operacji na tekstach. Ów schematyzm jest pozytywnym aspektem estetyki stawiającej opór próbom upolitycznienia, wykorzystania przez niszczycieli kultury. Umożliwia wprawdzie coś w rodzaju „wolnej gry” w obrębie danych przyswojonych drogą zmysłową, lecz jest ona ograniczona tymi danymi 
i kategoriami, a przede wszystkim „formami zmysłowości”, dlatego bywa twórcza (Doda-Wyszyńska, 2016). Inaczej mówiąc, trzeba sobie uświadamiać ograniczenia mocy myślenia, żeby móc tę moc wykorzystać. Nikt inny nie da nam tej mocy jak inni myśliciele, których myśl możemy twórczo rozwinąć. Nie trzeba bać się wpływu kanonu, do którego humaniści powinni zachęcać. Nie każdy humanista musi być Szekspirem czy Kantem, ale jeżeli jest w stanie zaprosić do uczestnictwa w swoim kanonie, spełnił swoją funkcję.

Gdybym musiała ograniczyć się, jak Bloom, do dwudziestu sześciu autorów, którzy ukształtowali moje spojrzenie filozoficzne na świat, to wymieniłabym tych (w kolejności alfabetycznej): Hannah Arendt, Roland Barthes, Jean Baudrillard, Pierre Bourdieu, Michel de Certeau, Gilles Deleuze, Jacques Derrida, Michel Foucault, Anthony Giddens, René Girard, Martin Heidegger, Carl Gustaw Jung, Immanuel Kant, Søren Kierkegaard, Feliks Koneczny, Thomas Kuhn, Jacques Lacan, Niklas Luhmann, Jean-François Lyotard, Marshall McLuhan, Blaise Pascal, Charles Sanders Peirce, Henri Poincaré, Jacques Rancière, Tomasz z Akwinu, Slavoy Žižek. Bez nich czułabym się bezradna, każdy z wymienionych wniósł do mojego życia coś ważnego, istotnego, prawdziwą zmianę, a nawet rewolucję w myśleniu. Zawsze któryś z nich pojawia się w bibliografii, nieważne na jaki temat piszę. Z niektórymi trwam od początku zainteresowania filozofią (Akwinata i Pascal), niektórych odkryłam dużo później niż przy pierwszym kontakcie z ich tekstami (Barthes, Peirce), wielu pojawiło się w moim życiu przez przypadek, sama bym po nich nie sięgnęła (Lacan, Luhmann). W moim przypadku znakomita większość to Francuzi, może ta francuska forma uprawiania filozofii, eseistyczna, jest mi najbliższa? Ubolewam, że w zestawie znalazła się tylko jedna kobieta. Może to kiedyś się zmieni.

Bez któregokolwiek z moich kanonicznych, filozoficznych autorów moje doświadczanie świata byłoby dużo uboższe. Jeśli chociaż jeden z nich jest na liście kogokolwiek, to znaczy, że mam sobie z tym człowiekiem dużo do powiedzenia.

\section{Literatura}

Barthes, R. (1979). Wykład (fragmenty wykładu inauguracyjnego w Collège de France 7 stycznia 1977 roku), tłum. T. Komendant. Teksty, 5, 9-29.

Barthes, R. (2000). Mitologie, tłum. A. Dziadek. Warszawa: KR.

Baudrillard, J. (2006). Przemoc wirtualnej i zintegrowanej rzeczywistości, tłum. M. Salwa. Sztuka i Filozofia, 29, 15-31. 
Bloom, H. (2019). Zachodni kanon. Ksiq̨żki i szkoła wieków, tłum. B. Baran, M. Szczubiałka. Warszawa: Aletheia.

Broch, H. (1998). Kilka uwag o kiczu i inne eseje, tłum. D. Borkowska, J. Garewicz, R. Turczyn. Warszawa: Czytelnik.

Doda-Wyszyńska, A. (2016). Pułapki przedstawienia. Filozofia przez pryzmat praktyk montażu pojęć. Poznań: Wydawnictwo Naukowe Wydziału Nauk Społecznych UAM.

Doda-Wyszyńska, A. (2019). Zarzqdzanie martwymi. Ironia eschatologii. Poznań: Wydawnictwo Naukowe Wydziału Nauk Społecznych UAM.

Eco, U. (1996). Nieobecna struktura, tłum. A. Weinsberg, P. Bravo. Warszawa: KR.

Foucault, M. (2009). Le corps utopique; suivi de Les hétérotopies. Paris: Éditions Lignes.

Foucault, M. (2013). Kim pan jest, profesorze Foucault? Debaty, rozmowy, polemiki, tłum. K.M. Jaksender. Kraków: Libron.

Foucault, M. (2014). Rzq̨dzenie żywymi, tłum. M. Herer. Warszawa: Wydawnictwo Naukowe PWN.

Girard, R. (2018). Apokalipsa tu i teraz, rozmawiał B. Chantre, tłum. C. Zalewski. Kraków: WAM.

Luhmann, N. (2016). Pisma o sztuce i literaturze, tłum. B. Baran, Warszawa: Wydawnictwo Naukowe Scholar.

Łotman, J. (2008). Uniwersum umysłu. Semiotyczna teoria kultury, tłum. B. Żyłko. Gdańsk: Wydawnictwo Uniwersytetu Gdańskiego.

Readings, B. (2017). Uniwersytet w ruinie, tłum. S. Stecko. Warszawa: Narodowe Centrum Kultury.

Scheler, M. (2008). Resentyment a moralności, tłum. B. Baran. Warszawa: Aletheia.

Toffler, A. (1997). Trzecia fala, tłum. E. Woydyłło. Warszawa: Państwowy Instytut Wydawniczy. 